\title{
XIII. Yüzyıl Anadolu Sahasında Tasavvufî Hareketler ve Daemonik Düşünce
}

\author{
Kemal KAHRAMANOĞLU
}

Prof. Dr., Necmettin Erbakan Üniversitesi, Ahmet Keleşoğlu Eğitim Fakültesi, Türkçe ve Sosyal Bilimler Eğitimi Bölümü, Konya, Türkiye, kkahramanoglu@erbakan.edu.tr (Sorumlu Yazar/ Corresponding Author)

\begin{tabular}{ll}
\hline Makale Bilgileri & ÖZ \\
\hline Makale Geçmişi & Şerif Mardin, Türkiye'deki düşünce ve edebiyatın yüzeyselliğini, daemon yokluğuna bağlar. Ona \\
Geliş: 13.07.2020 & göre, "Daemonik", insan şahsiyetinin tümünü bir dalga gibi kaplama potansiyeli taşıyan herhangi \\
Kabul: 05.10.2020 & bir tabii eğilimdir. Cinsiyetin kudretini, yaratıcının inadını, kızgınlığın yakıcılı̆̆ını, iktidar hırsını \\
Yayın: 25.12.2020 & da insanın daemonik uzantıları sayar. Daemonik güç kavramını belirtmenin dilimiz açısından zor \\
Anahtar Kelimeler: & olduğunu ifade eden yazar, bunun sebebini, insanın "daemon" tarafının hem geleneksel hem de \\
Şerif Mardin, & çağdaş kültürümüzde örtülü kalmış ve bırakılmış bir insan davranışı ekseni oluşturmasına bağlar. \\
Daemon, & Daemon'un kabul edilmediği, maskelendiği ve yalnız "kötü" ile bir tutulduğu uygarlıklarda \\
Şeytan, & edebiyatın ve sanatın yüzeysel kalmaya mahkûm olduğunu ifade eden Mardin, tasavvufu dışta \\
Tasavvuf, & tutarak İslam resmi kültüründe ve Osmanlı kültüründe "daemon" "şer-şeytan" ile bir tutulduğundan \\
İslam. & yaratıcı bir güç olarak ortada olmadığını söyler. Ancak tasavvufu dışta tutarak, ona hiç temas \\
& etmemesi iddiasındaki en zayıf halkayı oluşturur. Çünkü tasavvufun tarihi boyunca şeytan, sadece \\
& kötü ile bir tutulmamış ve mutasavvıflar, Şerif Mardin'in aradığı daemonik tavrın en etkili \\
& örneklerini ortaya koymuşlardır. Bu bağlamda XIII. yüzyıl Anadolusunda ortaya çıan tasavvufi \\
hareketler çerçevesinde daemonik teşekküller incelenmeye çalış1lmıştır.
\end{tabular}

\section{Sufi Movements and Daemonic Thought in the 13th Century in Anatolia}

\begin{tabular}{|c|c|}
\hline Article Info & ABSTRACT \\
\hline $\begin{array}{l}\text { Article History } \\
\text { Received: } 13.07 .2020 \\
\text { Accepted: } 05.10 .2020 \\
\text { Published: } 25.12 .2020 \\
\text { Keywords: } \\
\text { Sharef Mardin, } \\
\text { Daemonic, } \\
\text { Devil, } \\
\text { Mysticism, } \\
\text { Islam. }\end{array}$ & $\begin{array}{l}\text { Sharef Mardin, connects the superficiality of thought and literature in Turkey to the daemon } \\
\text { absence. According to him, "Daemonic" is any natural trend that has the potential to cover the } \\
\text { entire human personality like a wave. It counts the power of gender, the persistence of the creator, } \\
\text { the burning of anger, and the ambition of power to daemonic extensions of man. Stating that it is } \\
\text { difficult for our language to state the concept of daemonic power, the author attributes this to the } \\
\text { fact that the "daemon" side of human constitutes an axis of human behavior that has been covered } \\
\text { and left behind in both traditional and contemporary culture. Stating that literature and art are } \\
\text { doomed to be superficial in the civilizations where Daemon was not accepted, masked and held } \\
\text { alone with "evil", Mardin is a creative force since it is held in "Islamic" and Ottoman culture with } \\
\text { "daemon", "evil-devil" by excluding Sufism. Tells you that you are not in the middle However, by } \\
\text { excluding Sufism, it forms the weakest link in the claim that it never touches it. Because, } \\
\text { throughout the history of Sufism, the devil has not only been kept with the evil and the Sufis have } \\
\text { revealed the most effective examples of the daemonic attitude that Sharef Mardin sought. In this } \\
\text { context, daemonic organizations were tried to be examined within the framework of the mysticism } \\
\text { movements emerging in the 13th century Anatolia. }\end{array}$ \\
\hline
\end{tabular}

Atıf/Citation: Kahramanoğlu, Kemal. "XIII. Yüzyıl Anadolu Sahasında Tasavvufî Hareketler ve Daemonik Düşünce". Selçuklu Medeniyeti Araştırmalarl Dergisi (SEMA) 5 (Aralık 2020), 128-135. https://doi.org/10.47702/sematr.2020.8 


\section{GíRiş}

Şerif Mardin, aydınlarımızın zihniyet dünyası üzerine yazdığı bir yazıda önemli bir tartışmaya yol açmıştır. Bu yazıda genel olarak Türk düşüncesinin ve edebiyatının sathi, yüzeysel ve derinlikten mahrum olduğu söyleniyor ve bunun sebebi de düşünce dünyamızda “daemon” yokluğuna bağlamıştır.

Daemonik düşünce nedir? Şerif Mardin yazısında Batı toplum tarihi içerisinde ortaya çıkan intellektüel-intellectuals, intelligentsia, literati ve les clers gibi kavramları tahlilinin ardından, birbirleriyle önemli farkları olan bu kavramları bizim tek bir "aydın" kavramına indirgememizden şikâyet ediyordu. Yazının ekseni buradan Batı'da muhalif, yenilikçi, öncü aydın tipinin ortaya çıkmasında, Batı kültürünün içine sızmış olan "daemonik" ögenin önemine kayıyordu. Bunlardan intelectuel ve intelligentsia' yı içlerindeki "daemonic"i serbest bırakan ve bilim ile sanatta öncüler olarak nitelendirip literati ve les clercs'i de içlerindeki daemonic'e ket vurup geleneği muhafaza eden, bilgiyi entelektüellerden farklı değerlendiren kişiler olarak tanımlıyordu. ${ }^{1}$

Bat1 Avrupa tarihi çizgisinde literati grubunun özelliklerini kaybetmesi ve değerleri koruyucu bir kişiden değerleri sorgulayıcı bir kişi olmaya başlamasını Batı'nın Rönesans'taki fikir tarihi ile paralel olduğunu ifade eden Şerif Mardin, Osmanlı'daki saray, medrese ve tekkede yetişen literati gruplarının, Batı'da olduğu gibi intellectuel konumuna yükselmediğinden söz eder.

Aydınlanma döneminde ortaya çıkıp da Aydınlanma rasyonelliğine muhalefet eden Romantiklere de bir önem atfeden Mardin, bu romantiklerin felsefi düşüncelerine aydınlanmacıların, muhafazakârların yapamayacağı kadar radikal bir görelilik kattıklarını söyler. Ona göre Romantikler ile düşünür, felsefi bir meşrulaştırıcıya kavuşmuştur. Mardin'in asıl vurguladığı husus da tam burada devreye girer. Çünkü romantikler böylece insanların içindeki "daemonik" güçlere de bir meşruiyet kazandırmış oluyorlar.

Daemonik güç nedir? Bunu açıkça belirtmenin dilimiz açısından zor olduğunu ifade eden yazar, bunun sebebini, insanın "daemon" tarafının hem geleneksel hem de çağdaş kültürümüzde örtülü kalmış ve bırakılmış bir insan davranışı ekseni oluşturmasına bağlar. "Daemonik", insan şahsiyetinin tümünü bir dalga gibi kaplama potansiyeli taşıyan herhangi bir tabii eğilimdir diyen yazar, cinsiyetin kudretini, yaratıcının inadını, kızgınlığın yakıcılığını, iktidar hırsını insanın daemonik uzantıları sayar. İnsan davranışının derinliklerine nüfuz edebilme de ancak insanın "daemon"u şuurunda kabul etmeye ve anlamaya bağlıdır. Bu açıdan Klasik trajedi "daemon"un önünde durulmaz gücü üzerinde bir yorumdur.

Aydınlanmanın akılcılığının insandaki daemonik güçlere ket vurmasını eleştiren entelektüellerden birisi de Edgar Morin'dir. Antropolog ve filozof Edgar Morin, küçük şaheseri “Aşk Şiir Bilgelik" kitabında, bu üç kavram üzerinden Aydınlanma düşüncesine önemli eleştiriler getirir. Aydınlatma kelimesinin her şeyi gün ışığına çıkarabileceğine inanıldığında tehlikeli hale geleceğini belirten Morin, aydınlatma 1şık verir ama aynı zamanda 1şı̆̆a direnen şeyi de açığa çıkarır, dipte karanlık bir şey olduğunu tespit eder der. Morin aydınlanma ile birlikte değer kaybına uğrayan aşk şiir ve bilgeliği yeniden hayata sokar. Şiirin en önemli beslendiği kaynak olan ve modernliğin logos adına yanılsama olarak düşündüğü mitosun basit bir üstyapı olmadığını hele bir yanılsama hiç olmadığını, derin bir insani gerçeklik olduğunu söyler. Soğuk akıl tarafından daima yanılsamalı bir gölge-olay olarak değerlendirilmesini kabul etmez. Morin, Mitos'un insani-toplumsal derinliğine yani gerçekliğine inandığını söyler. Morin, insan sadece sapiens değil aynı zamanda demens’tir der. Ona göre Demens muhayyilenin taşkınlıklarıdır ve yaratıcılığın şiirin aşkın da kaynağıdır. Çünkü insan sadece aklen yetersiz olmakla kalmayıp, aynı zamanda akıldışılığa doğuştan sahip hayvandır. Morin

\footnotetext{
${ }^{1}$ Şerif Mardin, Türkiye'de Din ve Siyaset (İstanbul: İletişim Yayınları, 2002), 206.
} 
aklilik (rationalité) ile aklileştirme'yi (rationalitision) birbirinden ayırır. "Akliliğimizi geliştirelim ama aklilik de bizzat gelişmesi esnasında aklın sınırların tanır ve aklileştirilemeyenle diyaloğa girer.” $\mathrm{Bu}$ anlamda akliliğin sadece Batı medeniyetine has olmadığını ilkel toplumlar da dâhil her toplumun aklilikle donanmış olduğunu söyler. Batı akliliği, aklileştirmeye çevirerek bugünkü soğuk rasyonel toplumu inşa etmiştir. Oysa bugün Asya'da yüzyıllardır var olmuş mültiseküler uygarlıkların sadece gerilik içermediklerini, Batı'da az gelişmiş olan ya da düpedüz varlığından habersiz olunan kültürel değerlere de sahip olduklarını göz önünde bulundurmayı sağlayan da bu aklîliktir.

Bilim ile şiirin arasında bir diyaloğun kurulabileceğine inanan Morin, çünkü der "bilim bir yandan insan nedir, yeri neresidir, başına neler gelecektir, ne umabilir gibi temel felsefi soruları yeniden keşfederken, harikulade şiirsellikte bir evreni ifşa eder bize." "Oysa bilimin eski evreni bütünüyle determinist, sürekli bir hareketin, durmayan bir duvar saatinin canlandırdığı kusursuz bir makinayd1, bunun içinde hiçbir şey olamazd1, yaratılamazd1, vuku bulmazd1.”

Nihayet Morin, Batı kültüründe şiir, insancıl kültür gibi uzağa atılmıştır. Serbest zaman, eğlenceye doğru itilmiş, alçaltılmış bir unsur haline gelmesinden şikâyet eder. Çünkü ona göre, Hölderlin'in dediği gibi insan bu dünyada şairane barınır ve şiir sadece edebi bir ifade biçimi olarak değil katılımdan coşkudan hayranlıktan duygu birliğinden sarhoşluktan taşkınlıktan ve tabii ki "ikinci hal"in tüm ifade biçimlerini içinde barındıran aşktan gelen bir "ikinci hal" olarak kabul edilmelidir. ${ }^{3}$ Fazla bilgeliğin çıldırtacağını söyleyen Morin, ancak şiirin ve aşkın çılgınlığı ile iç içe geçerek çılgınlıktan kaçınabileceğini ifade eder. ${ }^{4}$

Daemon'un kabul edilmediği, maskelendiği ve yalnız "kötü” ile bir tutulduğu uygarlıklarda edebiyatın ve sanatın yüzeysel kalmaya mahkûm olduğunu ifade eden Mardin, tasavvufu dışta tutarak İslam resmi kültüründe ve Osmanlı kültüründe "daemon" "şer-şeytan" ile bir tutulduğundan yaratıcı bir güç olarak ortada olmadığını söyler. Bu yüzden de bizde ortaya gerçek trajedi çıkacağına, Abdülhak Hâmit'in melodramları çıkmıştır. Çağdaş Türk edebiyatının bir tür fakirliğinin sırrı da buradadır. Literati'den entellectual konumuna gelemeyen Türk aydını da seçenek olarak ideologluk ve dedikodu yazarlığı kalmıştır. Bundan dolayı da Mardin'e göre çağdaş düşünürlerimiz arasında "Niettzchen" (vurgu yazara ait) yaratabilmemiz mümkün değildir. ${ }^{5}$

Şerif Mardin'in bu tezi haklı olarak birçok eleştiriye maruz kalmıştır. Bunlardan Nurdan Gürbilek ve Hasan Ünal Nalbantoğlu'nın eleştirleri dikkate değer. Gürbilek'in haklı olarak şikâyet ettiği husus, Türkiye'deki eleştirinin ki yalnız edebiyat eleştirisinde değil, topluma ya da kültüre yönelik eleştiride de reflekse dönüşmüş olan bir yaklaşım olan bir "yokluk" tespitiyle hatta onsuz yapılamayan şu cümle ile başlaması: Bizde felsefe yok, bizde roman yok, bizde trajedi yok, eleştiri yok birey yok. ${ }^{6}$ Şerif Mardin de bu yokluk listesine daemon'u eklemiş oldu. ${ }^{7}$

\footnotetext{
${ }^{2}$ Mardin, Türkiye'de Din ve Siyaset, 206.

${ }^{3}$ Mardin, Türkiye'de Din ve Siyaset, 7. “İkinci Hal” Morin için sapiens'in zıddı olan daemonik ögedir.

${ }^{4}$ Edgar Morin, Aşk, Şiir ve Bilgelik (Konya: Palet Yayınları, 2017), 14-40.

${ }^{5}$ Mardin, Türkiye'de Din ve Siyaset, 255-265.

${ }^{6}$ Mardin, Türkiye'de Din ve Siyaset, 94.

${ }^{7}$ Nurdan Gürbilek, bu yazının yankıları hakkında şunları söyler: “Türk edebiyatının yaratıcı kötülükten nasibini

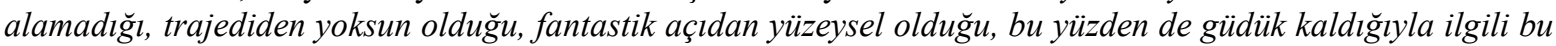
tez bir başka yazıda da yankısını buldu. Hatta çoğu zaman her kapıyı açan bir anahtara dönüştürüldü. Örneğin Hasan Bülent Kahraman, benzer esinler taşıyan Siyasal Romanın Ölümü adlı yazısında Türk edebiyatında trajedinin yokluğundan, fantastik olanın zayıflı̆̆ından, metafizik eksikliğinden, kötülük, şiddet ve yenilgi korkusundan yakınır Batı'nın kendi roman damarlarını işletmesine karşın Türkiye'de romanın özellikle de siyasi romanın kısırlaşmasını bu kültürel eksikliğe bağlar. 1970’lerin romancılarıyla Sevgi Soysal'ın Pınar Kür'ün Füruzan'ın romanları ile ilgili söyledikleri şunlar: Siyaset bu romanlarda yeni bir tipi gündeme getiriyordu. Kendi trajiği karşısında tavır almak ve onunla yüzleşmek zorunda olan birey. Ne var ki kültür
} 
Daemon konusunda önemle duran akademisyen yazarlardan birisi de Hasan Ünal Nalbantoğlu'dur. O da Mardin gibi düşünce dünyamızda durgunluğun ataletin yenilmesi ve gelişmenin sıçramanın oluşması için daemonik güçlere ihtiyacımız olduğuna inanır. Daimonsuz Bilim adlı yazısında konuyu geniş çerçevede ele alır: "Peki nedir bu daimon? Belki tam da "davranışçı" ya da "bilişselci" modern psikologların yaygın sanısının tersine, asla birey ruhuna indirgenemez öte yandan kritik dönemeçlerde kişiye de daha çok neyi yapmaması gerektiği yönünde telkinde bulunan ama gene de seçme şansı sunan bir kendini kaptırıs. Söz gelimi akademik bir kaptırma hem de güncel akıntı karşısında kürek sallayarak. Dikkat edilirse modern bilimin bildik kavramları, nedensellik, nedensonuç ilişkisinden dem vurmuyoruz burada. Daimon bireysel bir haslet değildir ama kişiye dışarıdan gelip onun beden canına nüfuz ederek kalıcı haslete dönüşebilen bir barbarca istiladır. Özetle akademik çalışmayı, bilgi üretmeyi bazıları için her ne pahasına yaşam boyu uğraşı da kişinin karakteri, huyu meşrebinin entegral parçası kılan her ne ise işte o daimondur". ${ }^{8}$

Mardin'in değerlendirmesi doğurgan olabilecek, düşünmeyi tetikleyici bir iddiadır diyen Nalbantoğlu, onun Türk aydınlarının literati konumundan entelektüel konuma geçemediği tespitine şerh koyar: “...... Öte yandan da meşrep'leri, huy'ların toplumsal vb. davalar uğruna kendilerini harcamaya sanki iten örneğin bazı geç Osmanlı aydınları düşünüldüğ̈̈nde de kanımca oldukça ihtiyatlı yaklaşılması gereken bir iddia bu." "Şerif Mardin çağdaş düşünürlerimiz arasında Nietzchen'yi yaratabilmemiz mümkün değildir tespitini ele aldığı ve bunu bir sanı olarak nitelendirdiği yazısında, Nalbantoğlu, haklı olarak şu son dönemlerde postmodern aydınların sıklıkla eleştirdiği Batı metafiziğine içkin dikotomik ayırımın hele de kutuplaştırmaların Mardin'in söylemine de sızmasından söz eder. Bu yazısının gayesini de yazar, "Şerif Mardin'in ülkemizde özellikle siyasal bilimlerin gelişmesine katkısını hiç de göz ardı etmeden kendisinin özellikle ülkemiz dışındaki arızalı durumu daimon eksikliğine bağlayan ama kanımca bizi aynı dikotomiler içine ittiğini düşündüğüm bir sanısı üzerinden giderek tartışmaya açmak" olarak dile getirir. ${ }^{10}$

Şerif Mardin'in tespitinde bize göre eleştirilmesi gereken asıl hususun sözünü ettiği bu yokluk dikotomisinde tasavvufu istisna olarak gösterip de tasavvuf ile ilgili herhangi bir tartışmaya girmemesidir. Hatta onu eleştirenlerin de tasavvuf ve daemonik düşünce konusunda herhangi bir değerlendirmede bulunmamaları ciddi bir eksiklik olarak görülüyor. Çünkü Şerif Mardin'in çağdaş düşünürlerimiz arasında arayıp da bulamadığı ve Hasan Ünal Nalbantoğlu'nun ise Jöntürklerde kısmen bulduğu "Niettzchen"i, en güzel bir tarzda tasavvufi düşüncede ve mutasavvıflarda, en çok da XIII. yüzyıl Anadolu sahasındaki mutasavvıf zümrelerin yaşama tarzları ve düşünme tarzlarında bulabilirdi. Bu tasavvufi zümrelerin ve öncüllerinin incelenmesi Şerif Mardin'in 'Daemon'un kabul edilmediği, maskelendiği ve yalnız "kötü" ile bir tutulduğu uygarlık" nitelemesinin ne kadar tartışmaya açık olduğunu ortaya koyar. Bir Hallac-1 Mansur'da Niçe'ci (Nietzchen) trajedinin daha üst

yaşamını oluşturan zihinsel yaklaşımın asla bir tragedya geleneğine dayanmaması daima ahlakçı olması, daima iyi'den ve doğru'dan yana tavır çalması, yenilgi'den korkması ve ona uzak durması bu romanların da belli bir çizgiyi aşamaması demekti.” Nurdan Gürbilek, Kötü Çocuk Türk (İstanbul: Metis Yayınları, 2012 ), 72.

8 Hasan Ünal Nalbantoğlu, Arayışlar (İstanbul: İletişim Yayınları, 2009), 59. Şerif Mardin bir yazısında akademik hayattaki daemonik noksanlığın giderilmesi için yaptığı bir teklifi anlatır. Yazısında daemonik öge için uçma tabirini istemeden de olsa kullanmak durumunda kaldığını belirterek, akademik hayattaki daemon ile ilgili şunları söyler: "Uçma dediğim zaman hani kendi başına müphem, belki de bir akademisyenin kullanmaması gereken hafiflikte bir kavramla işe başladım biliyorum. Bu başlık altında neler anlatacağımı ifade etmek için size [..] üniversitesinin kuruluş safhası ile ilgili bir anımı arz etmek istiyorum. Bundan birkaç yıl önce [...] üniversitesi öyle olacak, böyle olacak kalite nasıl olsun? Kaliteli Profesörler getirilsin.” diye konuşuyorduk. Bunların hepsi güzel fakat gerçek bir üniversite bir gün kendilerine "deli” ya da "uçuk" denen insanları bağrına basması gerekecektir dedim.” Nalbantoğlu, Arayışlar, 309.

${ }^{9}$ Mardin, Türkiye'de Din ve Siyaset, 72.

${ }^{10}$ Nalbantoğlu, Arayışlar, 9. 
bir boyutu bulmak mümkündür. Bu mutasavvıfların özellikle şeytan ve kötülük üzerine dile getirdiği ve çoğu zaman canlarıyla ödedikleri fikirler, şeytanın sadece kötülük ile bir tutulmadığını gösterir. Tek bir Hallac-1 Mansur bile bunu teyit etmek için yeterlidir. Yukarıda dediğimiz gibi, trajedisi Nietzche'den daha derin olan bu sufi, şeytan üzerine en cesur yorumların da sahibidir. Dünyada yalnızca iki gerçek muhavvid (tevhid, birlik ehli) tanıyan bu sufiye göre, şeytanı Allah'ın açık emrine rağmen O'ndan başka hiçbir şeye tapmamak için yaratılan bir varlığa secde etmemiştir. Bir rubaisinde şeytanın çığlığını dile getirir: "Benim başkaldırım Sen'i kutsi ilan etmek içindir." Hallac'a göre İblis İrade ile Emir arasında bırakılmıştı ve "elleri arkasında bağlı suya atılmıştı. Bu halde iken Allah ona dikkat et sakın 1slanma demişti."

Şeytanın trajik halinin bir takım sufi şairlere ilham kaynağı olduğunu söyleyen A. Schimmel, bu konuda en güzel şiir olarak da Senai'ninkini gösterir: “ Kalbi aşk simurgunun yuvası olan kovulmuş melek Allah'ın mekrinden yakınır: "Tanrı ezelden beri onu mahkum etmeye niyet etmişti ve cennetten kovulma sebebi olan Âdem'i yaratmıştı: Yoluma tuzak kurdu/Âdem tuzağın yemiydi/ Bana lanet damgasını basmak istedi/Yaptı istediğini topraktan Âdem bahaneydi”. ${ }^{12}$ Daha uç bir örnek de Moğol istilası altındaki Hindistan'da 1661 yılında idam edilen, ihtida etmiş bir Yahudi olan ve söyledikleri Schimmel'in tabiriyle Sünnileri şok eden Sermed'dir: Gir öğren Şeytan'dan kulluk nasıl yapılır/Bir Kıble seç, secde etme başka hiçbir şeyin önünde." ${ }^{13}$

Ahmed Gazali (v.1126) de "Tevhidi şeytandan öğrenmeyen kâfirdir." deme cesaretini göstermiştir. Bu tarz örneklerin daha 1lımlısını Attar ve Mevlânâ üzerinden genişletmek mümkündür. ${ }^{14}$ XIII. yüzyıldaki tasavvufi zümrelerin öncülleri konumundaki bu mutasavviflardaki daemonik düşünceyi, bu yüzyılın Anadolu'sunda çok çeşitli hale gelmiş olan tasavvufi zümrelerde de görmek mümkündür. $\mathrm{Bu}$ açıdan XIII. yüzyıl Anadolu sahası, tarihçilerden ilahiyatçılara felsefecilerden sosyologlara kadar sosyal bilimciler arasında çok farklı tarihî, dini, tasavvufi ve felsefi tartışmalara konu olmuştur.

Nitekim Ortaçağ Anadolusu'nda İslam'ın ayak izleri üzerine yazdığı kitabında Ahmet Yaşar Ocak, özellikle 1071 ile 1453 arası Türkiye'sinin toplumsal, kültürel ve entelektüel tarihini yazabilmenin çok zor olduğunu belirtir. Zorluğun ana sebebi olarak da dönemin uzunluğuna mukabil, resmi kroniklerdeki malzemenin o nispette sınırlı oluşunu gösterir. Çünkü Arşiv malzemeleri yoktur ve Selçuklu belgeleri ihtimaldir ki Moğol işgalinin ilk zamanlarındaki yağma ve tahrip sırasında ortadan kalkmışlardır. Bir başka ihtimal de Selçuklu Moğol iktidara diş bileyen Türkmenler tarafından çeşitli ayaklanma ve yağlanma esnasında yakılıp yırtılıp yok edilmişlerdir. ${ }^{15}$

Bu durum bu dönemde yaşanan siyasî, tasavvufî, felsefî hareketleri her türlü spekülasyonlara açık hale getirmiştir. Araştırmacılar da doğal olarak tarihi, siyasi, dini ve tasavvufi hadiseleri, sağlam bir tarihî belge üzerinden çok, kendi sahip oldukları kimliklerine, meşreplerine, ideolojilerine ve mezheplerine göre değerlendirmişlerdir.

XIII. yüzyı1 Anadolu sahası çok farklı tasavvufi akımlara sahne olmuş ve bu akımların bir kısmı etkilerini Osmanlı'ya hatta günümüze kadar devam ettirmişlerdir. Bu devirdeki tasavvufi zümrelerin sadece isimlerini yazmak bile ne kadar çoklu ve farklı tasavvufi meşrepler ile karşı karşıya

\footnotetext{
${ }^{11}$ Annemarie Schimmel, Tasavvufun Boyutları (İstanbul: Kabalc1 Yayınları, 1999), 209.

${ }^{12}$ Mardin, Türkiye'de Din ve Siyaset, 209.

${ }^{13}$ Mardin, Türkiye'de Din ve Siyaset, 210.

${ }^{14}$ Mevlânâ'ya göre İblis tek gözlüydü. Âdem'in topraktan yapılmış görüyordu ve bu yüzden de ben ondan daha hayırlıyım demiş, ateşin toprağa üstünlüğü ile böbürlenmişti. Ancak Allah'ın insana kendi nefesinden üflediği ve onu kendi suretinde yarattığ́ gerçeğini gözünden kaçırmıştı. Bu yüzden İkbal'in dediği gibi İblis, Âdem'in mirası olan ilahi sevgiden yoksun tek gözlü entelektüalizmin temsilcisidir.

${ }^{15}$ Ahmet Yaşar Ocak, İslam 'ın Ayak İzleri (İstanbul: Kitap Yayınevi, 2011 ), 247.
} 
olduğumuz gösterir: Kazeruniler, Evhadiler, Kübreviler, Vefailer, Rifailer, Ekberiler, Mevleviler, Babailer, Bektaşiler, Kalenderiler. ${ }^{16}$ Bunların dışında, konumları, durumları, kimlikleri ile ilgili karanlıkta kalan yönleri aydınlatılması beklenen Rum Abdallları, Câmiler, Şems-i Tebriziler, Medariler, Celâlîler gibi guruplar da üzerlerinde konuşmayı ve çalışmayı hak edecek öneme sahip dini zümreler de söz konusudur.

Ahmet Yaşar Ocak'ın da dediği gibi bu dönemdeki siyasi karışıklıklar, yağmalar gibi sebepler yüzünden resmi arşivlerden ve belgelerden mahrum olsak da bu derviş zümrelerinin özellikle tavır davranış giyim ve yiyimleri hakkında bilgilere sahibiz.

Meşhur Barak Baba (v.1307) beline taktığı sarı kırmız bir bez parçası dışında çıplak dolaşır, başına iki yanına birer manda boynuzu takıştırır, kırmızımsı sarık sararmış ve saçı ile bıyıklarını uzatıp sakalını kazırdı. Servet biriktirmezdi. Uzun değnekler, tef, davullar taşıyan müritleri de aynı görünümdeymişler. Müritler çalar Barak Baba ayı gibi oynayıp maymun gibi türkü çığırırmış. ${ }^{17}$ Rum Abdalları, Şems-i Tebriziler ve Celaliler "çahar darb" yani dört vuruş denen saç sakal bıyık ve kaşlarını tıraş ederlerdi. Haydariler ve Camiler ise sakallarını kesiyor ama bıyıklarını uzatıyorlardı. Haydarilerin demir halka, tasma bilezik kuşak bukağı ve zincire düşkündüler. Rum Abdalları özel baltalar, deri torbalar, büyük tahta kaşıklar ve âşık kemiği taşırlardı. ${ }^{18}$ Bütün bunları resmî, Ortodoks İslam'a karşı bir çeşit heterodoks veya anarşist tavır olarak nitelendirmek mümkündür. Bu tavırlarının arkasındaki düşüncelerine dair elimizde yeterli doküman ve belge olmaması dini ve tasavvufi tarihimiz açısından talihsizlik olsa da tavır ve davranışlarından Şerif Mardin'in aradığı daemonik ögelere daha modern bir deyimle anarşist tavra sahip olduklarını tahmin etmek mümkündür. Nitekim seçkin bilim adamı Nasıreddin Tusi bu zümreleri "dünyanın fazlalıkları" "şeytanın oyuncakları" olarak nitelendiriyor ve Hulagu Han'a Kalenderîlerin idam edilmesini salık veriyordu. ${ }^{19}$

İçlerindeki daemonik güçleri dizginle(ye)meyen bu zümreler ile ilgili çalışmaları ile tanıdığımız Ahmet T. Karamustafa, "Tanrının Kural Tanımaz Kulları" olarak nitelendirdiği bu zümreler üzerindeki bilgilerimizi eksik hatta hatalı bulur. Günümüzde zahitlik ile ilgili kapsamlı çalışmalar olmadığını söyler ve bu olgunun İslam dindarlık biçimlerinin tarihsel gelişiminde ayrı bir evre olarak bile tanınmadığından yakınır. Derviş dindarlığı olarak kabul ettiği bu zümrelerin yeni bir dindarlık tarzına sahip olmalarına rağmen halk dini kategorisinde değerlendirilmesine itiraz eder. Anarşist olarak da nitelendirdiği bu dervişlerin halk dini ve aşağı kültür alanına sürgün edilmesinin tarihi nedenlerine gider. Seçkinci tavrın, bu kural dışı dervişleri kaba yığınların dininin en üst sembolü gibi görmesini kabul etmez. Ahmet T. Karamustafa bu kaba olarak değerlendirilen dervişlerin okuma ve yazmasız kalabalıklar olmadığını tersine pek çok Müslüman entelektüelin gönlünü ve beynini kazandıklarını söyler. ${ }^{20}$ Kaldı ki tabiri caizse Ortodoks İslam'ın temsilcisi kabul edilen büyük mutasavvıf Mevlânâ'nın özellikle Kalenderîlerin ileri gelenleri ile samimi ilişkiler içinde olduğunu hatta onları öven şiirler yazdığını biliyoruz. Gölpınarlı bu şiirlerden birçok örnek almıştır. Bir tanesi de şudur: Hak kokusunu kalenderin ağzından ara. Adam-akıllı ararsan şüphe yok ki mahrem olur aradığını bulursun. ${ }^{21}$ Mevlânâ mesnevisinde Şeytan ile Muaviye'yi çatıştırır. Burada da şeytan öyle

\footnotetext{
${ }^{16}$ Ayrıntılı bilgi için bk. Rauf Kahraman Ürkmez, Selçuklular Zamanında Anadolu'da Tasavvufî Zümreler (Konya: Çizgi Yayınları, 2020).

${ }_{17}^{17}$ Ahmet T. Karamustafa, Tanrının Kural Tanımaz Kulları (İstanbul: YKY Yayınları, 2007), 11.

${ }^{18}$ Mardin, Türkiye'de Din ve Siyaset, 28-29.

${ }^{19}$ Mardin, Türkiye'de Din ve Siyaset, 15.

${ }^{20}$ Tanrının Kural Tanımaz Kulları, 12-18.

${ }^{21}$ Abdülbaki Gölpınarlı, Mevlânâ Celâleddin Hayatı, Eserleri, Felsefesi (İstanbul: İnkılap Yayınları, 1999), 6163. İslam öncesi Türk şiirinde bile daemonik ögeler bulmak mümkündür. Nitekim Fuat Köprülü şiir, büyü, musiki ve çılgınlığı birleştiren eski Türk şairleri hakkında şu önemli bilgileri verir: "Tonguz'ların "şaman”, Altay Türklerinin "kam” Yakutların “oyun”, Kırgızların “bahşı” Oğuzların “ozan” dedikleri eski Türk şairleri
} 
bildik tanıdık kılığın dışında, yani sadece kötülük simgesi olarak belirmez. Sembolik olarak aklı temsil eden Muaviye'yi akli bir takım argümanlarla alt etmeye çalışır:

"Rivayet ederler, Muaviye köşkte bir bucakta uyumuştu. Köşkün kapısı içerde kilitliydi, çünkü Muaviye, halkın gelip gitmesinden yorulmuştu. Ansızın onu birisi uyandırdı. Muaviye, gözünü açınca adam gözden sir oldu. Kendi kendisine "Köşke kimse giremez. Bu küstahlıkta, bu cürette bulunan kim acaba" dedi. Kapı ardında bir herif gördü. Adam kapıya sinmiş, yüzünü perde ile örtmüş, gizlenmişti. Muaviye, "hey sen kimsin adın ne? diye sordu. Adam "adım açıkça söyleyeyim şaki İblis" diye cevap verdi. Muaviye, "Niye gayret ettin, beni niçin uyandırdın, bana doğru söyle, aykırı konuşma" dedi. Şeytan "namaz vakti geldi, hemen mescide koşmak gerek. Mustafa, mânâ incisini delerek, acele edin, ibadetleri vakti geçmeden yapın buyurdu" dedi. Muaviye, "hayır hayır senin böyle bir maksadın olamaz. Bana hayra delil olasın, imkânı mı var bunun? Şeytan dedi ki, "Biz evvelce melektik. İbadet yoluna canla başla düzülmüştük. Yol saliklerine mahremdik, arş sakinlerine hem dem. Biz de bu şarabın sarhoşlarındandık, biz de kapının âşıklarındandı. Tutalım Âdem'e secde etmem hasettendi. Ama o haset de aşktan meydana geldi, inattan inkârdan değildi. Her haset, şüphesiz dostluktan meydana gelir. Sevgili ile başkaları bir arada oturunca haset baş gösterir. Onun oyununda bundan başka bir oyun yoktu ki. Oyna dedi.

Ben ne bilirim ki ona katayım. Bir tek oyunum vardı, oynadım, kendimi kaldırıp belaya attım. Belada da onun lezzetlerini tatmak istedim. Ona mat oldum mat oldum mat oldum. Küfür olsun, iman olsun onun eliyle dokunmadır, onundur. Emir ona dedi ki, "bunlar doğru. Fakat bunlardan senin payın eksiktir. Tanrı seni yakıcı bir hâle getirmiş, bütün hırsızların üstadı etmiştir. Tanrı ile yüz yüze konuştum. Ey düşman senin hilene karşı ben kim oluyorum? Filozof zeki Firavun'un aklı körleşti, senin yüzünden bir şey anlamaz oldu. Ebu Leheb senin yüzünden nâehil oldu, Ebul Hakem de senin yüzünden Ebu Cehil kesildi. Ey bu satranca nam için yüz binlerce ustayı mat eden. Sen hile denizisin, halk bir katreden ibaret. Sen dağ gibisin selim kalpli insanlarsa bir zerre. İblis Muaviye'ye Hak beni aslanla köpeği imtihan etmek için yarattı, halisle kalbi ayırt etmek için halk etti. Bu otları niçin ortaya koyarım? Hayvan hangi cinstendir meydana çıksın diye. Kurt, ceylandan bir yavru doğursa onun kurt yahut ceylan oluşunda şüphe edilir. Önüne otla kemik koy. Eğer kemiğe gelirse köpektir, ota

\footnotetext{
"sahir-şairler” olarak yani büyücü şairler olarak nitelendirilirdi. Çünkü bu şairler, sihirbazlık, rakkaslık, musikişinaslık, hekimlik gibi birçok vasıfları kendilerinde toplarlar ve halk üzerinde büyük saygı kazanırlardı. Gökyüzündeki Tanrılara türlü amaçlar için kurban sunmak, ölünün ruhunu yerin dibine göndermek, ölüm hastalık gibi kötü cinler tarafından gelen işleri büyü ile önlemek, hastaları tedavi etmek gibi sosyal vazifeleri üstlenirlerdi. Bütün bu işler için ayinler düzenlenir ve "sahir-şairler" bu ayinlerde kendilerinden geçmiş halde tepinip sıçrarken, bir takım şiirler inşad ederler, bunları kendi musiki aleti ile özel bir beste ile söylerlerdi. Bu esnada tavırları da oldukça ürkütücüdür. Çünkü dehşet verici sıçramalar ile gözlerini korkunç bir şekilde dolaştırır, dişerini gıcırdatır, bir çılgın gibi etrafına vurarak sarsılırdı. O kadar ki bu vecd halinde etrafına zarar vermesin diye sıkı sıkıya tutulmak zorunda kalırdı. Bahşı'ların kıpkırmızı demirleri yaladıklarından, bedenlerine şişler batırdıklarından, çıplak ayakla kızgın demirler üzerinde yürüdüklerinden, bu yürüme esnasında da demirin üstüne su dökülmüş gibi cızladığından dehşetle bahsedilirdi."21 Fuat Köprülü, Türk Edebiyatı Tarihi (İstanbul: Ötüken Yayınları, 2014), 25. Köprülü ne yazık ki bu şiir örneklerinin elimizde olmadığını da ifade eder. Diğer yandan Antik Yunan Felsefesi Terimleri Sözlüğü (İstanbul: Paradigma Yayınları, 2004) adlı klasikleşmiş eserinde Francis E. Peters daemon ilgili maddede (özetle) şunlar söyler: "daimon veya daimonion Tanrl ile kahraman arasında bir yerde bulunan doğaüstü varlık veya şey, dai-omai taksim etmek, kemirmek, yutmak, kader, alınyazlsı, daimon tanrı, tanrıça, ilah, ilahe, tanrl, tanrılık, ilah, uluhiyet, bir kimsenin cini (genius) klsmeti veya kaderi. Daimones tanrllar ile insanlar arasındaki bağlantı halkasını oluşturan altın çağın insanlarına ruhlarına verilen addı. Bu yüzden bedenden dünyadan ayrılan ruhlar için kullanılmıştır. Daimonao tanrısal bir öc alıcıya maruz kalmak, kötü bir cinin tutsă̆ olmak, deliliğe sürüklenmek, cin çarpmak." Yazarın bu tarifleri, Köprülü’nünün bizim eski şairlere musallat olan cin ve ruhlara benzerliği dikkat çekicidir.
} 
meylederse şüphe yok ceylan cinsindendir. Kahır ile lütuf birbirine eş oldu. Bu ikisinden bir hayır ve şer âlemi doğdu. Sen otla kemiği göster, nefs ve can gıdasına arz et. Nefsin gıdasını isterse aşağılıktır, ruh gıdasını isterse serverdir. Peygamberler ibadetlerini arz ederler, düşmanlar şehvetlerini. Muaviye, ey yol vurucu delil getirme, beni kandırmaya yol bulamazsın. Ben delil getirmede sana üst olamam. Senin her sözünde bir şey vardır, her sözünde yüzbinlerce sihir gizlidir. Ey fitneci İblis niçin beni uyandırdın doğru söyle? İblis, Ey düşüncelere dalan, doğruyu ve yalanı nasıl anladın? dedi. Muaviye, peygamber nişanesini bildirmiş, kalp ile halisi anlamak için mehenk vermiş. Halk heva ve arzu sarhoşudur. Onun için senin yalanını dinler. İblis, birçok hileye düzene kalktıysa da Muaviye onun inadını inkârını dinlemedi. İblis, eğer namazın fevt olsaydı, namaz geçseydi, bu cihan sana nursuz kapkaranlık kesilecekti. Bu ziyandan ağlayacak, figan edecektin. O teessüf, o figan, o niyaz, yüzlerce zikirden namazdan üstün olacaktı İstedim ki öyle bir ah etmeyesin, bu suretle de öyle bir yola sahip olmayasın dedi. Muaviye, işte şimdi doğru söyledin. Senden bu beklenir, layığın budur. Sen örümceksin, ancak sinek tutabilirsin. Hâlbuki ben sinek değilim, zahmet etme a köpek. Sen beni uyandırdın ama o uyandırış, uykunun ta kendisiydi. Bana gemi gösterdin ama gösterdiğin gemi, girdaptan ibaretti. Sen beni daha iyi bir hayırdan mahrum etmek için hayra sevk ettin dedi.",22

\section{SONUÇ}

Sonuç olarak diyebiliriz ki Şerif Mardin'in başlattığını söyleyebileceğimiz, Türk düşünce, kültür ve sanat hayatını yüzeyselliğe mahkûm ettiğine inanılan daemonik yoksunluk, verimli bir tartışma ortamı oluşturacakken, Nurdan Gürbilek'in güzel ifadesiyle hemen hemen her kilidi açan bir anahtar konumuna gelmiş ve birkaç değerli muhalif seslerin dışında unutulmaya mahkûm edilmiştir. Batı metafiziği ve Oryantalizm'in içimize sızdırdığı var-yok dikotomilerinden sıyrıldığımız ve hem günümüz hem de Selçuklu ve Osmanlı dönemindeki tasavvufi eserler olmak üzere klasik metinleri bu sızdırmanın ve sıyrılmanın ötesinde bir kavrayışla ele aldığımız takdirde düşünce sanat ve kültür dünyamızdaki zenginliklerin farkına varacağımız şüphesizdir.

\section{KAYNAKÇA}

Gölpınarlı, Abdülbaki. Mevlânâ Celaleddin Hayatı, Eserleri, Felsefesi. İstanbul: İnkılap Yayınları, 2005.

Gürbilek, Nurdan. Kötü Çocuk Türk. İstanbul: Metis Yayınları, 2012.

Hasan Ünal, Nalbantoğlu. Arayışlar. İstanbul: İletişim Yayınları, 2009.

Karamustafa, T. Ahmet. Tanrının Kural Tanımaz Kulları. İstanbul: YKY Yayınları, 2007.

Köprülü, Fuat. Türk Edebiyatı Tarihi. İstanbul: Ötüken Yayınları, 2014.

Mardin, Şerif. Türkiye'de Din ve Siyaset. İstanbul: İletişim Yayınları, 2002.

Morin, Edgar. Aşk, Şiir, Bilgelik. Konya: Palet Yayınları, 2017.

Nalbantoğlu, Hasan Ünal. Arayışlar. İstanbul: İletişim Yayınları, 2009.

Ocak, Ahmet Yaşar. İslam'ın Ayak İzleri. İstanbul: Kitap Yayınları, 2011.

Schimmel, Annemarie. Tasavvufun Boyutları. İstanbul: Kabalcı Yayınları, 1999.

Rûmî, Mevlânâ Celâleddîn. Mesnevi. çev. Veled İzbudak. 2. Cilt. İstanbul: MEB Yayınları, 1991.

Peters, Francis E. Antik Yunan Felsefesi Terimleri Sözlüğ̈̈. İstanbul: Paradigma Yayınları, 2004.

Ürkmez, Rauf Kahraman. Selçuklular Zamanında Anadolu'da Tasavvufi Zümreler. Konya: Çizgi Yayınları, 2020.

${ }^{22}$ Mevlânâ Celâleddîn Rûmî, Mesnevi, çev. Veled İzbudak (İstanbul: MEB Yayınları, 1991), 2/200-214. 